\title{
Peningkatan Kreatifitas Melalui Funcooking pada Kelompok A RA Az Zahra Kebayoran Baru Jakarta Selatan
}

\author{
Dwi Puji Lestari \\ Program Studi Pendidikan Islam Anak Usia Dini \\ STAI Al Aqidah Al Hasyimiyyah Jakarta \\ Email: pldwi1022@gmail.com
}

Received February 2019, Accepted March 2019, Published April 2019

\begin{abstract}
The purpose of this research is how to increase creativity through fun cooking in group $A R A A z$ Zahra Kebayoran Baru South Jakarta. This study was carried out in 4-5 years old group A children of 16 children. This research is an action research with Kemmis and Taggart model which consists of 4 stages namely (plan, action, observation and reflection). This study consisted of 2 cycles, with each cycle as many as 8 meetings. Data collection techniques are using observation, field notes, and documentation. Data analysis uses quantitative and qualitative. Quantitative data analysis is carried out with statistical descriptions to compare pre cycles to cycles II. The stages of qualitative analysis are data reduction, data display and verification. The results showed that there was an increase in creativity through the method of fun cooking. The results of the study in cycle I, and cycle II, the results of which increased significantly from before the action only $37.5 \%$ of the number of children in the class increased to $81 \%$ in cycle 2. The average value of the percentage in the preaction was 33.20\%; cycle 1 is 59.76\% and cycle 2 is $84.375 \%$. The increase from cycle 1 to cycle 2 reached $24.615 \%$.
\end{abstract}

Keywords: Creativity, Funcooking and Action Research

Abstrak: Tujuan dari penelitian ini adalah bagaimana meningkatkan kreatifitas melalui fun cooking pada kelompok A RA Az Zahra Kebayoran Baru Jakarta Selatan. Penelitian ini dilakukan pada anak kelompok A 4-5 tahun yang berjumlah 16 anak. Penelitian ini adalah penelitian tindakan dengan model Kemmis dan Taggart yang terdiri dari 4 tahap yaitu (rencana, tindakan, observasi dan refleksi). Penelitian ini terdiri dari 2 siklus, dengan masing-masing siklus sebanyak 8 kali pertemuan. Teknik pengumpulan data yaitu menggunakan observasi, catatan lapangan, dan dokumentasi. Analisis data menggunakan kuantitatif dan kualitatif. Analisis data kuantitatif dilakukan dengan deskripsi statistik untuk membandingkan pra siklus sampai pada siklus II. Tahap-tahap analisis kualitatif adalah reduksi data, display data dan verifikasi. Hasil penelitian menunjukkan bahwa terdapat peningkatan kreatifitas melalui metode fun cooking. Hasil penelitian secara siklus I, dan siklus II yang hasilnya mengalami peningkatan yang berarti dari sebelum tindakan hanya 37,5\% dari jumlah anak dikelas meningkat menjadi $81 \%$ di siklus 2. Nilai rata-rata persentase pada pra tindakan yaitu 33,20\%; siklus 1 yaitu 59,76\% dan siklus 2 yaitu 84,375\%. Peningkatan dari siklus 1 ke siklus 2 mencapai 24,615\%.

Kata Kunci : Kreatifitas, Funcooking dan Penelitian Tindakan

\section{PENDAHULUAN}

Setiap anak pada dasarnya sudah memiliki potensi kreatif, namun dalam perkembangannya potensi kreatif itu dapat hilang karena pengaruh lingkungan. Potensi kreatif atau tingkat kreativitas anak akan selalu meningkat sesuai dengan pendidikan anak, hal ini seiring dengan tingkat kematangan, kecerdasan, dan pengalaman anak.

Guru, orangtua, masyarakat dan pemerintah mengemban tugas dan tanggung jawab untuk mengoptimalkan potensi kreatif yang dimiliki anak. Sehingga anak dapat tumbuh dan berkembang sesuai potensi mereka. Untuk itu diperlukan upaya yang kreatif agar anak dapat tumbuh optimal dengan kondisi yang nyaman dan menyenangkan. Salah satunya adalah dengan mengembangkan konsep dan aplikasi pengembangan kreativitas di taman kanakkanak karena anak memiliki potensi kreatif yang alami.

Pendidik sebagai orang terdekat anak di sekolah merupakan pengaruh yang besar untuk memotivasi, memfasilitasi, dan memberikan pembelajaran yang terbaik untuk mengembangkan kreativitas. Pendidik haruslah memahami bahwa setiap individu memiliki potensi kemampuan yang berbedabeda dan terwujud karena interaksi yang dinamis antara keunikan individu dan pengaruh lingkungan. 
Konsep yang harus diterapkan oleh pendidik dalam pembelajaran yaitu harus berpusat pada anak, menarik, dan didasarkan pada minat anak. Berpusat pada anak yaitu anak sebagai subyek dalam pembelajaran dan memberikan keleluasaan kepada anak untuk berkarya. Pembelajaran yang dirancang oleh guru hendaknya menarik dan berdasarkan minat anak untuk merangsang perhatian dan rasa ingin tahu anak sehingga anak merasa nyaman dan tidak mudah bosan.

Salah satu bidang pengembangan yang dilakukan oleh RA Az Zahra adalah pengembangan seni. Seni yang dimaksud disini meliputi kemampuan mengeksplorasi dan mengekspresikan diri, berimajinasi dengan gerakan, musik, drama dan beragam seni lainnya (seni lukis, seni rupa, kerajinan) serta mampu mengapresiasi karya seni, gerak dan tari serta drama. Hal ini sesuai dengan Peraturan Menteri Pendidikan Dan Kebudayaan Republik Indonesia No. 137 Tahun 2014 Tentang Standar Nasional Pendidikan Indonesia.

Pendidik RA Az Zahra berusaha memberikan pelayanan pengembangan seni kreativitas dengan melakukan kegiatan, menggambar bebas, mewarnai, melipat, dan bermain membentuk dengan plastisin juga kreasi barang bekas. Akan tetapi kegiatan yang sangat mendominasi yaitu, menggambar, mewarnai, melipat dan bermain plastisin. Kurangnya variasi kegiatan kreativitas sangat berpengaruh bagi perkembangan kreativitas anak.

Berdasarkan hasil observasi yang telah dilakukan oleh peneliti di RA Az Zahra ternyata hanya 6 dari 16 siswa yang perkembangan kreativitasnya mulai berkembang. Artinya baru 37,5\% siswa yang mulai berkembang kreativitasnya. Sedangkan 10 siswa atau $62,5 \%$ siswa belum berkembang kreativitasnya. Hal ini ditandai dengan produk yang dihasilkan oleh anak masih sama dari kegiatan satu dengan yang lain, misalnya ketika kegiatan menggambar, umumnya satu anak menggambar rumah yang lainpun ikut menggambar rumah. Demikian pula saat membuat prakarya masih kurang inisiatif gagasan sendiri, lebih banyak minta bantuan guru.
Masalah utama disekolah adalah cara belajar lebih banyak terpaku pada buku paket, lembar kerja dan buku tulis. Hampir semua aspek pengembangan di setiap sentra didominasi oleh tugas dari LKS dan buku paket. Kegiatan lebih banyak terfokus pada pengembangan kognitif dan bahasa. Hal ini membuat guru dan siswa menjadi bosan dan kurang berkembang kreativitasnya. Mengatasi kelemahan tersebut guru berusaha memberikan kegiatan seni bervariasi seperti membuat topi, lampu lampion atau kreasi lain pada tiap tema pelajaran. Namun, hasilnya belum maksimal. Anak lebih banyak minta bantuan guru dan belum memiliki inisiatif mengembangkan imajinasinya.

Selain itu, masalah pola pikir dan tuntutan orangtua ternyata juga mempengaruhi perkembangan kreativitas anak. Hampir semua wali murid yang mendaftarkan anaknya di TK berasumsi bahwa anak berhasil jika pandai dalam calistung. Mengatasi hal tersebut, pihak sekolahpun beberapa kali mengadakan parenting. Namun, ternyata hanya beberapa dari walimurid yang mulai memahami aspek perkembangan anak. Hal ini disebabkan pula karena kenyataan di lapangan yang dialami oleh walimurid bahwa saat mendaftar anakanak di Sekolah Dasar ternyata anak dituntut sudah bisa calistung (membaca, menulis dan berhitung) apalagi materi pelajaran di SD saat ini sudah terkesan berat dimasyarakat, sehingga umumnya walimurid merasa khawatir dan ketakutan jika anak mereka tidak bisa atau belum lancar membaca, menulis dan berhitung saat lulus TK. Dampak negatif dari kekhawatiran walimurid, akhirnya mereka beranggapan bahwa kreativitas dan aspek motorik tidaklah terlalu penting bagi anak. Hal ini ditandai oleh kurang peduli dan lambannya respon orangtua membantu anak dan guru dalam beberapa kegiatan seperti saat diminta mengumpulkan barang bekas seperti kardus,toples, botol untuk prakarya. Wali murid lebih sering meminta PR atau tugas tambahan menulis dan berhitung untuk dibawa kerumah. Bahkan tak jarang anak meminta PR karena takut dimarahi oleh orangtua, hal ini pula yang akhirnya membuat anak beranggapan bahwa sekolah TK adalah tempat belajar calistung, bukan bermain. 
Masalah ini tentunya tidak bisa terus menerus dibiarkan terjadi. Sebagai pendidik, guru merasa bertanggung jawab atas perkembangan anak didiknya. Pihak sekolah, terutama guru berusaha mengoptimalkan kegiatan disetiap sentra dengan harapan perkembangan anak akan terlihat jelas dari tiap sentra. Hasilnya diakhir semester satu terlihat sekali anak lebih banyak yang unggul di perkembangan kognitif dan bahasa namun belum berkembang daya kreativitasnya.

\section{Berdasarkan latar belakang permasalahan tersebut, khususnya pada pembelajaran di sentra seni maka peneliti tertarik untuk melakukan penelitian tindakan kelas dengan menerapkan kegiatan fun cooking di RA Az Zahra untuk meningkatkan kreativitas anak.}

Keputusan untuk melakukan kegiatan fun cooking dipilih berdasarkan hasil kesepakatan para guru dan kepala sekolah. Dengan pertimbangan saat ini sekolah perlu mencari suasana belajar yang berbeda, sebuah terobosan baru dan inovatif dalam pengajaran yang dapat mengembangkan kreativitas dan mencakup seluruh aspek perkembangan serta sesuai dengan karakteristik anak. Selain itu kegiatan Fun cooking masih sangat jarang diadakan disekolah. Umumnya kegiatan fun cooking dilakukan dengan melakukan kegiatan luar seperti berkunjung ke tempat pizza ataupun dapur restoran cepat saji. Tentunya kegiatan tersebut membutuhkan biaya yang cukup mahal. Untuk itu sekolah mencoba melakukan kegiatan fun cooking disekolah, selain biaya lebih murah, juga dapat meningkatkan kreativitas guru dan anak. Selain itu, acara dan kegiatan seni kuliner saat ini sedang berkembang marak, baik di sosial media maupun televisi yang ternyata menarik minat anak-anak dan sebagian besar wali murid, sehingga diharapkan melalui pemilihan kegiatan ini, kerjasama dengan wali murid menjadi lebih mudah.

Adapun kegiatan fun cooking yang akan diterapkan pada penelitian ini yaitu dengan menggunakan metode bermain. Bermain fun cooking yaitu bermain mengolah bahan makanan dengan cara dan suasana yang menyenangkan. Fun cooking dilakukan sesuai dengan prinsip pembelajaran anak usia dini yaitu berpusat pada anak dan menyenangkan. Dimulai dari pengenalan dapur, perlengkapan memasak, dan uji coba resep yang mudah, praktis dan tidak memakan waktu lama. Anak disuguhkan dengan sumber belajar berupa bahan makanan yang akan diolah menjadi makanan yang siap disajikan. Anak-anak akan bereksplorasi menggambar dan membentuk dengan menggunakan bahan makanan seperti menghias roti dan biskuit, kreasi buah, menghias donat dan bento. Kegiatan tersebut tidak membutuhkan waktu lama dalam proses kegiatannya, juga dalam biaya masih bisa dipilih yang paling minimal anggarannya.

Kegiatan baru ini diharapkan dapat membantu meningkatkan perkembangan kreativitas anak serta memberi pengalaman baru bagi mereka dalam kegiatan pembelajaran yang berbeda dari biasanya, lebih menyenangkan dan tidak membosankan, sehingga mereka menjadi lebih percaya diri, berani mengungkapkan ide dan imajinasinya serta semangat dalam kegiatan belajar di sekolah.

\section{Kreativitas}

Kreativitas secara etimologis adalah memunculkan sesuatu yang baru tanpa ada contoh sebelumnya. Suatu produk yang dikategorikan kreatif akan memenuhi sifatsifat baru dan unik pada akhirnya, meskipun unsur-unsur dasar memang sudah ada sebelumnya. Kata "kreatif" merupakan kata yang berasal dari bahasa Inggris To Create yang berarti mencipta. Pengertian kata kreatif dan kreativitas menurut Kamus Besar Bahasa Indonesia, kreatif adalah memiliki daya cipta dan kreativitas adalah kemampuan untuk mencipta.

James J .Gallagher mengatakan bahwa "Creativity is a mental process by which an individul creates new ideas and product, in fashion that is novel to him or her" (kreativitas merupakan suatu proses mental yang dilakukan individu berupa gagasan atau produk baru, atau mengkombinasikan antara keduanya yang pada akhirnya akan melekat pada dirinya) (Rahmawati \& Kurniati, 2011).

Menurut Supriadi, Kreativitas adalah kemampuan seseorang untuk melahirkan 
sesuatu yang baru baik berupa gagasan maupun karya nyata yang relatif berbeda dengan yang ada. Kreativitas adalah hasil dari interaksi antara individu dan lingkungannya. Seseorang mempengaruhi dan dipengaruhi oleh lingkungan dimana ia berada, dengan demikian baik perubah didalam individu maupun di dalam lingkungan dapat menunjang atau dapat menghambat upaya kreatif (Munandar, 2012).

Bicara tentang kreativitas, erat hubungannya dengan kerja otak. Otak manusia adalah massa protoplasma yang paling kompleks yang pernah dikenal di alam semesta. Inilah satu-satunya organ yang sangat berkembang sehingga ia dapat mempelajari dirinya sendiri. Jika dirawat oleh tubuh yang sehat dan lingkungan yang menimbulkan rangsangan, otak yang berfungsi dapat tetap aktif dan kreatif selama lebih dari seratus tahun (Porter \& Hernacki, 2002).

Anak usia empat tahun, struktur neuro motor sensorik dan kognitif emosional berkembang sebanyak 80 persen dan kecerdasan yang lebih tinggi mulai berkembang. Setelah itu alam berpengaruh mengalirkan energi untuk bergerak kecara berfikir yang lebih tinggi. Jika dirawat dengan benar,semuanya akan berkembang. Jika anak merasa terancam atau tidak ada contoh,maka kecerdasan ini pada akhirnya akan mandek.

Tahapan kreativitas anak sejalan dengan tahapan perkembangan kognitif anak. Maka kreativitas dapat ditinjau melalui proses perkembangan kognitif Jean Piaget (Hafizallah, 2016):

Tahap Sensori - Motori, tahap ini dialami pada usia 0-2 tahun. Menurut piaget pada tahap ini anak belum berkembang kreativitasnya, sebab pada masa ini anak masih bersifat refleksi,belum memiliki konsep sebab akibat.

Tahap Pra-Operasional, tahap ini berlangsung pada usia 2-7 tahun. Pada akhir tahap ini kreativitas anak sudah tumbuh dan berkembang karena anak sudah mulai mengembangkan memori dan telah memiliki kemampuan untuk memikirkan masa lalu dan masa mendatang. Anak juga mampu menjelaskan peristiwa alam disekitarnya.

Tahap Operasional Konkret, berlangsung pada usia 7-11 tahun. Pada tahap usia ini kreativitas anak semakin berkembang. Anak sudah mampu berfikir logis, mengerti identitas diri, menyesuaikan diri dan mampu mengimajinasikan sesuatu.

Tahap Operasional Formal, yaitu pada usia 11 tahun keatas. Pada tahap ini menurut piaget tahap ini sangat potensial bagi perkembangan kreativitas karena anak remaja sudah memiliki pemikiran yang logis juga kemampuan problem solving.

Ihat Hatimah mengemukakan beberapa bentuk kreativitas pada anak usia dini, yaitu berupa tiga hal:

1. Gagasan/berpikir kreatif, yang meliputi: a) berpikir luwes yaitu anak yang mampu mengungkapkan pengertian lain yang mempunyai sifat sama, mampu memberikan jawaban yang tidak kaku, mampu berinisiatif. b) berpikir orisinil yaitu anak mampu mengungkapkan jawaban yang baru, anak mampu mengimajinasi bermacam fungsi benda. c) berpikir terperinci yaitu anak yang mampu mengembangkan ide yang bervariasi, mampu mengerjakan sesuatu dengan tekun, mampu mengerjakan dan menyesuaikan tugas dengan teliti dan terperinci. d) berpikir menghubungkan yaitu anak yang memiliki tingkat kemampuan mengingat masa lalu yang kuat, memiliki kemampuan menghubungkan masa lampau dan masa kini.

2. Aspek sikap, yang meliputi: a) rasa ingin tahu yaitu anak tersebut senang menanyakan sesuatu, terbuka terhadap situasi asing, senang mencoba hal-hal yang baru. b) ketersedian untuk menjawab pertanyaan - pertanyaan yang dilontarkan guru, tertarik untuk memecahkan masalah-masalah baru. c) keterbukaan yaitu anak yang senang beragumentasi, senang terhadap pengalaman orang lain. d) percaya diri yaitu anak yang berani melontarkan berbagai gagasan, tidak mudah dipengaruhi orang lain, kuat pendirian, memiliki kebebasan berkreasi. e) berani mengambil resiko yaitu anak yang tidak ragu mencoba hal baru, selalu 
berusaha untuk berhasil, dan berani mempertahankan.

3. Aspek karya, yang meliputi: a) permainan yaitu anak yang berani memodifikasi berbagai mainan, mampu menyusun berbagai bentuk mainan. b) karangan yaitu anak mampu menyusun karangan, tulisan atau cerita, mampu menggambar hal yang baru, memodifikasi dari yang telah ada.

Berdasarkan uraian diatas dapat disintesiskan bahwa hakikat kreativitas anak adalah kemampuan anak untuk menciptakan atau mengkombinasikan sesuatu yang baru baik berupa gagasan maupun karya dengan aspek yang diukur dalam penelitian yaitu memiliki kelancaran, kelenturan, keaslian dan kerincian serta dipengaruhi oleh lingkungan dimana ia berada.

\section{Fun Cooking}

Istilah fun cooking terbentuk dari dua unsur kata yaitu fun dan cooking. Keduanya diambil dari bahasa Inggris yaitu fun yang artinya jenaka, kegembiraan, atau bersifat senang dan cooking artinya memasak (Kehelay \& Andreas, 1976).

Kata Fun, merajuk pada suasana yang menyenangkan, penuh kegembiraan dan secara psikologis bisa diartikan tanpa beban. Belajar akan terasa nyaman dan menyenangkan jika kondisi baik fisik, psikis, maupun lingkungan juga mendukung (Fathurrahman, 2015).

Menurut Peraturan Menteri Pendidikan Dan Kebudayaan RI No.146 tahun 2014 tentang Kurikulum 2013 PAUD, pembelajaran pada anak usia dini haruslah didukung oleh lingkungan yang kondusif yaitu lingkungan yang menarik, menyenangkan, aman dan nyaman bagi anak (Departemen Pendidikan dan Kebudayaan, 2014).

Suasana yang menyenangkan, siswa akan bersemangat dan mudah menerima berbagai kebutuhan belajar. Dalam suasana yang menyenangkan pula anak akan mampu mengikuti dan menangkap materi pelajaran yang sulit menjadi mudah. Pembelajaran yang menyenangkan dapat terjadi apabila hubungan interpersonal antara guru dan peserta didik berlangsung baik. Banyak cara yang dapat dilakukan untuk membuat suasana pembelajaran berlangsung menyenangkan. Dalam konsep PAIKEM, pembelajaran yang menyenangkan dapat dicapai karena peserta didik aktif selama proses pembelajaran. Selain itu, motivasi belajar juga mempunyai andil yang tinggi terhadap suasana senang belajar. Supaya motivasi belajar tetap tinggi, guru perlu memberikan umpan balik terhadap hasil belajar yang telah dicapai atau tugas yang telah diselesaikan oleh peserta didik (Mulyatiningsih, 2010) .

Unsur kata kedua yaitu Cooking yang maknanya memasak, Kamus Besar Bahasa Indonesia mengartikan memasak yaitu mengolah atau membuat penganan. Buku Boga Dasar menjelaskan bahwa memasak adalah membuat suatu bahan mentah menjadi matang dengan tujuan agar dapat dimakan. Menurut para ahli kuliner, memasak adalah proses pemberian panas (application of heat) sehingga bahan yang dimasak akan dapat dimakan (eatable),lezat di lidah (palatable), aman dimakan (safe to eat), mudah dicerna (digistible), dan berubah penampilannya (change its appearance) (Lubis, 2013).

Berdasarkan dari definisi tersebut dapat diketahui bahwa tujuan memasak adalah:

1. Membuat bahan makanan lebih mudah dicerna oleh tubuh

2. Membuat makanan aman dimakan

3. Meningkatkan rasa dan aroma pada makanan

4. Meningkatkan penampilan dan warna pada makanan

5. Melengkapi dan Menyeimbangkan kandungan gizi jika dicampur dengan bahan makanan lain.

Sebenarnya, tujuan utama belajar memasak untuk anak -anak bukanlah untuk mendapatkan keahlian memasak. Aktivitas memasak justru dinyatakan sangat berpengaruh positif terhadap tumbuh kembang anak. artinya, berbagai kegiatan yang dilakukan dalam acara memasak bisa menolong anak untuk berkembang optimal 
(Educenter, 2018). Adapun kemampuan yang bisa dipelajari anak dari memasak adalah :

1. Melatih motorik halus. Dalam memasak, gerakan motorik halus adalah gerakan yang terjadi karena adanya koordinasi gerakan otot kecil seperti jari tangan untuk melatih keterampilan ini, kegiatan memasak yang dapat dilakukan contohnya memeras adonan,mengocok telur.

2. Melatih persepsi visual, koordinasi tangan dan mata, misalnya saat menuang lelehan coklat ke dalam cetakan.

3. Mengembangkan kemampuan kognitif. Contohnya saat menakar, mengetahui ukuran bahan,mengetahui warna dan rasa, perubahan bentuk dan mampu mengetahui bahan-bahan serta fungsi alat memasak.

4. Mengembangkan kemampuan berbahasa. Melalui memasak anak dapat menambah perbendaharaan kata seperti menyebutkan nama-nama bahan dan alat memasak, berdiskusi tentang menu yang akan dipilih, membaca resep masakan. Anak juga belajar memahami instruksi yang diberikan guru.

5. Mengembangkan nilai moral dan sosial emosional. Dengan belajar memasak, anak terlatih untuk disiplin, menjaga kebersihan, bersabar, bertanggung jawab terhadap pekerjaannya serta menjalin komunikasi dengan teman.

6. Mengembangkan kreativitas, melalui memasak anak dapat mencoba mengungkapkan dan menciptakan ide kreasi sesuai imajinasinya.

Beberapa tahapan yang harus dilalui anak dalam belajar memasak yaitu: mengenal bahan makanan, mengenal peralatan memasak, mengenal persiapan memasak, mengenal cara memasak dan mengenal cara penyajian makanan (Educenter, 2018).

Tahap pertama sebelum memasak, guru perlu mengenalkan jenis dan bahan makanan yang bisa dimasak bersama anak. Mengenalkan kandungan gizi yang ada di dalam bahan masakan seperti manfaat vitamin, mineral pada sayur dan buah, protein pada lauk pauk dan karbohidrat pada makanan pokok. Anak juga belajar mengenal tekstur bahan makanan mulai dari yang cair, lembut hingga kasar. Tahap kedua yaitu mengenalkan peralatan memasak beserta fungsinya seperti kompor untuk memasak, wajan untuk menggoreng, panci untuk merebus, dandang untuk mengukus, pisau untuk memotong. Selain itu guru harus benar-benar memberi pengertian pada anak tentang manfaat dan bahaya yang akan terjadi jika anak tidak berhati-hati dalam menggunakan peralatan tersebut.

Tahap ketiga yaitu mengenal persiapan memasak. Dalam tahapan ini anak harus mengembangkan daya ingat supaya bisa memasak sesuai dengan resep yang tersedia. Secara umum tahapan memulai memasak yang dapat dilakukan anak yaitu proses memotong dan membersihkan bahan masakan seperti memotong dan membersihkan sayuran dan buah.

Tahap keempat yaitu mengenal cara memasak. Ada beberapa teknik memasak sederhana yang dapat dikenalkan pada anak antara lain merebus (boiling), mengukus (steaming), menggoreng (frying) dan memanggang (baking). Tahap kelima yaitu penyajian masakan. Setelah proses memasak selesai, langkah terakhir yang harus dilakukan adalah menyajikan masakan. Tahap ini merupakan tahap yang menyenangkan untuk anak karena anak bisa belajar berkreasi sekaligus menuangkan ide imajinasi dalam menyajikan masakan yang sudah jadi.

Ada beberapa cara untuk mengatur aktivitas memasak bersama siswa dalam kegiatan fun cooking yaitu dengan strategi (Garden-Enchaned Nutrition Education, 2018):

1. Kelompok kecil yaitu siswa dibagi menjadi kelompok kecil dan masingmasing kelompok menyiapkan resep yang sama, bahan dan peralatan memasak.

2. Kelompok besar yaitu siswa dibagi dalam beberapa kelompok lalu menyiapkan 
resep,alat dan bahan yang berbeda dari resep yang sama.

3. Cooking show (demonstrasi) yaitu meniru acara memasak, guru di depan kelas mempraktekan cara memasak. Mengundang salah satu anak untuk membantu memasak, dan sebagian menonton.

4. Production Line, yaitu guru mempersiapkan bahan - bahan pada lokasi yang telah ditentukan, anak-anak berjalan menyusuri berbaris antri sambil membawa piring atau mangkok, lalu menyendok sendiri makanan yang ingin disajikan. Misalnya membuat salad buah. Guru telah menyiapkan aneka buah, selada, mayonaise di meja dan anak tinggal meraciknya sendiri.

Menurut growing minds farm to school program dalam panduan memasak bersama Anak Pra sekolah, ada tiga kategori usia dini yang dibedakan dalam kegiatan fun cooking yaitu (Growing Minds, 2018):

1. Anak usia 2-3 tahun, aktivitas yang mampu dilakukan yaitu mencelupkan makanan, mencuci dan memetik sayuran, merobek roti.

2. Anak usia 4 tahun, belajar menggunakan tangan mereka, contoh kegiatannya yaitu menuang cairan ke dalam adonan, kocok minuman dalam wadah tertutup, mencuci sayuran, meletakkan barang sesudah digunakan.

3. Anak usia 5-6 tahun belajar mengendalikan otot kecil jari. Kemandirian dan fokus mereka sudah lebih berkembang. Aktivitas yang dapat dilakukan yaitu: membuat jus, mengupas telur, memotong, menakar, mengatur meja, menghias hidangan, menyiapkan sajian dan membersihkan meja setelah masak.

Di dalam kegiatan fun cooking anak belajar seni memasak. Dari mulai memilih resep, bahan, mempersiapkan peralatan, hingga menyajikan hasil karyanya. Prinsip dalam pemilihan resep kegiatan fun Cooking ini yaitu sehat, mudah dan cepat dibuat serta murah biayanya. Banyak resep masakan yang dapat di buat bersama anak dalam kegiatan fun cooking, antara lain menghias donat, melukis diatas biskuit dan roti, membuat bento sederhana, aneka kreasi buah dan minuman segar, yang semuanya itu dapat menstimulasi kreativitas anak.

Fun Cooking termasuk salah satu kegiatan dalam lingkup perkembangan seni, sesuai dengan Permendikbud Nomor 137 Tahun 2014 Tentang Standar Nasional Pendidikan Anak Usia Dini, Bab IV pasal 1 ayat 7. Seni yang dimaksud meliputi kemampuan mengeksplorasi dan mengekspresikan diri, berimajinasi dengan gerakan musik, drama, dan beragam bidang seni lainnya (seni lukis, seni rupa, kerajinan) serta mampu mengekspresikan karya seni, gerak dan tari, serta drama (Departemen Pendidikan dan Kebudayaan, 2014).

Fun Cooking juga merupakan kegiatan pembelajaran yang berorientasi pada pengembangan kecakapan hidup. Hal ini sejalan dengan pedoman pembelajaran yang tertuang dalam Permendikbud No 146 Tahun 2014 Tentang Kurikulum 2013 Pendidikan Anak Usia Dini bahwa pengembangan kecakapan hidup dilakukan secara terpadu baik melalui pembelajaran untuk mengembangkan pengetahuan dan keterampilan maupun melalui pembiasaan dan keteladanan (Departemen Pendidikan dan Kebudayaan, 2014).

Selain itu Fun Cooking juga merupakan salah satu cara mengembangkan kreativitas anak dalam golongan bermain menciptakan produk (hasta karya) dan bermain ekperimen. Seperti dijelaskan oleh Rachmawati dan Kurniati bahwa kegiatan membuat produk hasta karya dapat meningkatkan kreativitas anak (Rahmawati \& Kurniati, 2011).

Berdasarkan uraian diatas maka dapat disintesiskan bahwa hakikat fun cooking adalah suatu kegiatan seni memasak dalam mengolah atau menyajikan hasil masakan yang terdiri dari berbagai bahan dan cara serta dilakukan secara terencana dan sesuai tahapan serta dilakukan dalam suasana gembira dan menyenangkan seperti saat bermain. 
Jurnal PG-PAUD Trunojoyo : Jurnal Pendidikan dan Pembelajaran Anak Usia Dini, Volume

6, Nomor 1, April 2019, hal $18-28$

\section{METODE}

Penelitian ini menggunakan pendekatan penelitian tindakan kelas (Classroom Action Research). Penelitian tindakan merupakan pencermatan terhadap kegiatan belajar berupa tindakan, yang terjadi di dalam kelas dan dilakukan secara bersama . Penelitian tindakan kelas melakukan penelitiannya di dalam kelas yang mempunyai masalah secara keseluruhan murid. Penelitian ini bertujuan untuk memecahkan masalah yang ada dalam kelas ataupun kelompok tertentu. Penelitian ini merupakan penelitian tindakan kelas secara kolaborasi yaitu penelitian tindakan kelas yang dimana peneliti bekerja sama dengan guru kelas untuk memecahkan masalah yang ada dalam kelas tersebut. penelitian kolaborasi ini pihak yang melakukan tindakan adalah guru itu sendiri, sedangkan yang melakukan pengamatan terhadap proses tindakan yaitu peneliti.

Tujuan pokok dalam penelitian tindakan kelas adalah memberikan pelayanan pembelajaran yang lebih baik bagi siswa. Tujuan utama penelitian tindakan kelas adalah pengembangan keterampilan proses pembelajaran yang dihadapi oleh guru di kelasnya. Melalui penelitian tindakan kelas guru dapat mengembangkan berbagai macam model metode pengajaran yang bervariasi sehingga kegiatan belajar menjadi tidak membosankan.

Desain penelitian yang digunakan pada penelitian ini adalah model penelitian Kemmis dan Mc Taggart. Model yang dikemukakan oleh Kemmis dan McTaggart pada hakekatnya berupa perangkat-perangkat atau untaian-untaian dengan satu perangkat terdiri dari empat komponen, yaitu perencanaan, tindakan, pengamatan dan refleksi. Keempat komponen yang berupa untaian tersebut dipandang sebagai satu siklus. Oleh karena itu, pengertian siklus pada kesempatan ini adalah suatu putaran kegiatan yang terdiri dari perencanaan, tindakan, pengamatan dan refleksi.

\section{HASIL DAN PEMBAHASAN}

Setelah dilakukan observasi awal, tindakan siklus I, dan tindakan siklus II dihasilkan peningkatan perkembangan anak yang dapat dilihat dalam tabel 1 .

Tabel 1. Data Hasil Kegiatan Pra Siklus, Siklus 1 Dan Siklus 2

\begin{tabular}{|c|c|c|c|c|c|c|c|}
\hline \multirow[t]{2}{*}{ No } & \multirow{2}{*}{$\begin{array}{c}\text { Kode } \\
\text { Respo } \\
\text { nden }\end{array}$} & \multicolumn{2}{|c|}{ Pra siklus } & \multicolumn{2}{|c|}{ Siklus 1} & \multicolumn{2}{|c|}{ Siklus 2} \\
\hline & & Skor & $\%$ & Skor & $\%$ & Skor & $\%$ \\
\hline 1. & A1 & 12 & 25 & 33 & 68,7 & 45 & 93,7 \\
\hline 2. & A2 & 12 & 25 & 33 & 68,7 & 42 & 87,5 \\
\hline 3. & A3 & 12 & 25 & 33 & 68,7 & 42 & 87,5 \\
\hline 4. & A4 & 12 & 25 & 24 & 50 & 42 & 87,5 \\
\hline 5. & A5 & 24 & 50 & 27 & 56,2 & 42 & 87,5 \\
\hline 6. & A6 & 12 & 25 & 24 & 50 & 42 & 87,5 \\
\hline 7. & A7 & 12 & 25 & 30 & 62,5 & 36 & 75 \\
\hline 8. & A8 & 24 & 50 & 30 & 62,5 & 42 & 87,5 \\
\hline 9. & A9 & 24 & 50 & 33 & 68,7 & 48 & 100 \\
\hline 10. & A10 & 12 & 25 & 30 & 62,5 & 42 & 87,5 \\
\hline 11. & A11 & 12 & 25 & 30 & 62,5 & 42 & 87,5 \\
\hline 12. & A12 & 24 & 50 & 24 & 50 & 42 & 87,5 \\
\hline 13. & A13 & 12 & 25 & 24 & 50 & 36 & 75 \\
\hline 14. & A14 & 12 & 25 & 24 & 50 & 36 & 75 \\
\hline 15. & A15 & 24 & 50 & 33 & 68,7 & 42 & 87,5 \\
\hline 16. & A16 & 24 & 50 & 33 & 68,7 & 45 & 93,7 \\
\hline $\mathbf{J m}$ & Total & 237 & 550 & 465 & $\begin{array}{c}968 \\
7\end{array}$ & 666 & $\begin{array}{c}1387, \\
5\end{array}$ \\
\hline $\begin{array}{l}\text { Ha } \\
\text { Ra }\end{array}$ & Rata- & 14,81 & $\begin{array}{c}34,3 \\
7\end{array}$ & 9,56 & $\begin{array}{c}60,5 \\
4\end{array}$ & 41,62 & 86,72 \\
\hline
\end{tabular}


Volume 6, Nomor 1, April 2019, hal 18 - 28

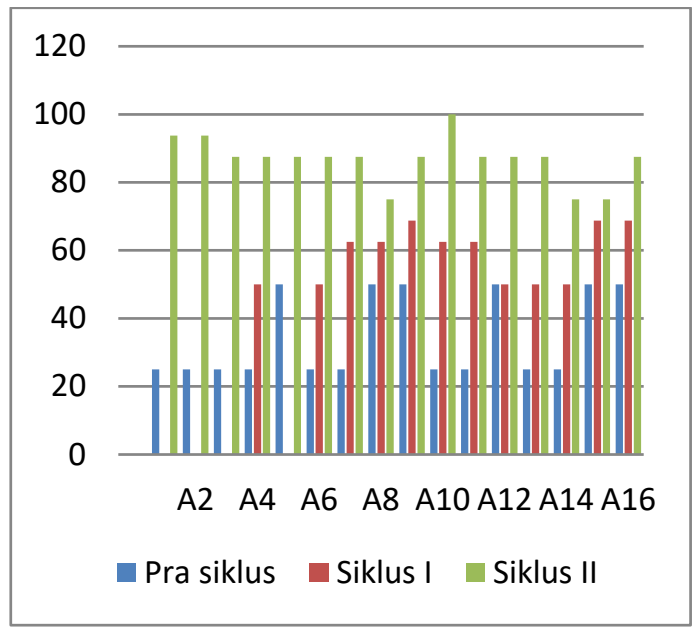

Gambar 1. Hasil Peningkatan Kreativitas Anak Usia 5-6 Tahun Dari Pra Siklus, Siklus 1 Dan Siklus 2

Berdasarkan hasil yang didapat pada tabel 1 dan gambar 1 tersebut, terlihat skor atau nilai indikator yang diperoleh anak pada pra siklus cenderung sama dan masih dibawah $50 \%$. Pada siklus 1 skor indikator yang diperoleh anak mulai meningkat, yang semula hanya mencapai skor 6 dan 8 meningkat ke skor 10 hingga 12. Persentase perkembanganpun mulai menunjukkan hasil yang sesuai harapan yaitu diatas $50 \%$. Pada siklus 2 terlihat jelas peningkatan skor indikator yang diperoleh setiap anak. pada siklus 2 ini hampir tidak ada anak yang memperoleh skor 8. Umumnya meningkat hingga skor 12 bahkan ada yang mencapai skor 14 dan 16 dari skor maksimal yaitu 16 . Dari segi persentase pun dapat terlihat dari yang awalnya hanya $37,5 \%$ di pra siklus meningkat hingga mencapai $81 \%$ dari jumlah anak yang ada dalam penelitian.

Berdasarkan hasil diatas, maka sesuai kesepakatan kriteria ketuntasan atau kriteria keberhasilan yang disepakati oleh peneliti dan kolaborator bahwa anak akan dianggap berhasil sesuai harapan apabila anak mencapai hasil minimal $75 \%$ dari kriteria keberhasilan. Apabila sudah tercapai $75 \%$ maka penelitian akan dihentikan. Mengingat kesepakatan tersebut dan berdasarkan hasil yang diperoleh anak mencapai $84 \%$ maka penelitian inipun berhenti di siklus 2 .

Sejalan dengan hasil penelitian McCabe dan Malefyt dalam penelitiannya disebutkan bahwa Masakan rumahan mencontohkan kreativitas konsumsi kerajinan karena juru masak terlibat dalam merancang dan membuat serta mengkonsumsi makan. Tentu saja, desain makanan keluarga hari ini terjadi dalam konteks yang lebih luas dari sistem pangan industri global dan tren melawan penggunaan lokal segar makanan untuk membuat hidangan yang lebih sehat, menarik dan penuh warna, adapu hubungannya dengan kreatifitas dalam antara fun cooking dan creativitas adalah Masakan rumah berorientasi kepada orang lain dalam banyak hal. Koki memiliki panci, wajan, dan peralatan favorit di dapur seperti wajan atau panci rebusan yang mereka sukai untuk digunakan dalam memasak. Seperti komoditas lain, panci dan wajan ini memperoleh kehidupan sosial (Kopytoff, 1986) dan berisi kenangan keberhasilan dan kegagalan memasak, dan pengalaman makan bersama. Dengan menggunakan pot dan wajan ini dengan sejarah sosial dan maknanya, komoditas makananditransformasikan menjadi makanan keluarga atau benda yang tidak dapat dicabut (Miller, 1998). Panci dan wajan favorit memberikan salah satu contoh harta yang mencerminkan hubungansifat kreativitas.

Semua hal yang disimpan oleh juru masak di dapur (mis. Rempah-rempah, staples dapur dan barang kering) dianggap sebagai elemen yang diperlukan untuk digabung sesuatu yang cocok dengan selera keluarga. Harta dapur menunjukkan akar darimasak di rumah sebagai penghasil makanan untuk rumah tangga. Mereka juga menunjukkan caranya kreativitas atau perubahan berkembang dari struktur atau organisasi (harta)dapur. Kreativitas mengalir dari konteks yang terorganisir dan terstruktur yang bersifat sosial akar. Perasaan terinspirasi untuk memasak juga mengarahkan dunia hubungan sosial dengan cara itu para ibu mengungkapkan perhatian dan kepeduliannya pada diri sendiri dan orang lain. Inspirasi kreatif berasal dari pikiran emosional orang lain, dan bukan hanya acuh tak acuh. Makanan itu sendiri dapat diobjekkan, tetapi memasak dan menyiapkan makanan adalah pribadi dan transformasi sosial dari makanan itu menjadi sesuatu yang dimaksudkan untuk 
menyenangkan atau menggairahkan lainnya. Persiapan makan melibatkan tindakan kreatif membangun hubungan sosial, ikatan pribadi, dan berbagi ruang emosional dengan orang lain. Persiapan makanan sangat penting untuk bagaimana kita membayangkan dan membangun hubungan dengan orang lain (Miller, 1998). Seperti cinta bakti dalam mengatasi pekerjaan sehari-hari belanja sementara membosankan.

\section{SIMPULAN}

Berdasarkan hasil penelitian yang telah dilakukan, dapat disimpulkan bahwa kreativitas anak kelompok B TK Fatahillah, Mekarsari,Cimanggis, Kota Depok dapat ditingkatkan dengan bermain fun cooking. Hal ini dapat dilihat dari perbandingan hasil observasi yang telah dilakukan pada pra tindakan, siklus I, dan siklus II yang hasilnya mengalami peningkatan yang berarti dari sebelum tindakan hanya $37,5 \%$ dari jumlah anak dikelas meningkat menjadi $81 \%$ di siklus 2. Nilai rata-rata persentase pada pra tindakan yaitu $33,20 \%$; siklus 1 yaitu $59,76 \%$ dan siklus 2 yaitu $84,375 \%$. Peningkatan dari siklus 1 ke siklus 2 mencapai $24,615 \%$.

Penelitian untuk meningkatkan kreativitas dengan menggunakan fun cooking ini telah memotivasi anak untuk berdaya pikir dan menciptakan sesuatu yang berbeda dan orisinil. Hal ini terlihat ketika anak mampu mengerahkan ide dan gagasannya dalam kegiatan bermain fun cooking. Anak lain memang sangat berpengaruh bagi anak untuk menciptakan sesuatu yang berbeda. Namun hasil dari bermain fun cooking ini, terdapat keberagaman produk yang dihasilkan oleh anak. Keberagaman produk ini adalah sebuah peningkatan anak dalam indikator mempunyai gagasan yang baru dan original.

Kegiatan bermain fun cooking bagi anak-anak kelompok B TK Fatahillah menjadi sebuah pengalaman yang baru dan menarik. Anak mendapatkan keleluasaan untuk bereksplorasi dengan berbagai media yang biasanya hanya menggunakan media kertas, pensil, dan crayon untuk mengembangkan kreativitas anak kini meningkat memakai media lain. Dengan media bahan makanan, anak merasa media yang baru lebih menarik dan semakin tertarik karena hasil olahan dapat dimakan dan anak menjadi senang. Merekapun menjadi lebih lancar dalam berkomunikasi, mampu mengeksplor bakat dan potensi kreatif yang mereka miliki.

\section{DAFTAR PUSTAKA}

Departemen Pendidikan dan Kebudayaan. (2014). Permendikbud Tentang Kurikulum 2013 Pendidikan Anak Usia Dini. Jakarta: Departemen Pendidikan dan Kebudayaan.

Departemen Pendidikan dan Kebudayaan. (2014). Permendikbud Tentang Standar Nasional Pendidikan. Jakarta: Departemen Pendidikan dan Kebudayaan.

Educenter. (2018). Memasak Untuk AnakAnak.

Fathurrahman. (2015). Model-Model Pembelajaran Inovatif. Jogjakarta: ArRuzz Media.

Garden-Enchaned Nutrition Education. (2018). Retrieved from Cooking With Kids: http://nrich.match.org/content/id/1069 8/cooking.pdf

Growing Minds. (2018). Growing Minds. Retrieved from Cooking With Preschool Children: http://growingminds.org/.pdf

Hafizallah, Y. (2016). Golden Age. Jurnal Ilmiah Tumbuh Kembang Anak UsiA Dini; Volume 2 Nomor 1, 53.

Kehelay, W., \& Andreas, M. (1976). Kamus Lengkap Praktis CBSA. Surabaya: Fajar Mulia.

Lubis, C. (2013). DASAR 1, Bahan Ajar Sekolah Menengah Kejuruan Program Keahlian Tata Boga. Jakarta: Kemendikbud BOGA. 
2828 Jurnal PG-PAUD Trunojoyo : Jurnal Pendidikan dan Pembelajaran Anak Usia Dini, Volume 6, Nomor 1, April 2019, hal 18 - 28

Munandar, U. (2012). Dasar-Dasar Pengembangan Kreativitas Anak Berbakat. Jakarta: Rineka Cipta.

Porter, B. D., \& Hernacki, M. (2002). Quantum Learning. Bandung: Kaifa.

Rahmawati, Y., \& Kurniati, E. (2011). Strategi Pengembangan Kreativitas pada Anak Usia Taman Kanak-Kanak. 